\title{
How Store Environment and Sales Promotion Influence Positive Emotions and Unplanned Purchases
}

\author{
Indah Fatmawati ${ }^{1, *}$ and Latifah Dinar ${ }^{1}$ \\ ${ }^{1}$ Universitas Muhammadiyah Yogyakarta, Yogyakarta Indonesia \\ *Corresponding author. Email: indahfatmawati@umy.ac.id
}

\begin{abstract}
This study investigates how store environments and sales promotion affect positive emotions and unplanned purchases. Store environment and sales promotion are the independent variables that affect positive emotions as the mediating one. The predictor variable is unplanned purchases. The setting of the study is a global hypermarket. The sample size is 159 respondents, selected by using the purposive sampling method. The data analysis technique utilized in this research was Structural Equation Modeling (SEM), with AMOS 21. The instrument testing is employing validity, reliability, and normality test. The research results revealed that the store environment and sales promotion positively and significantly affected positive emotion. The store environment had a significant positive effect on unplanned purchases. However, sales promotion had no significant impact on unplanned purchases. Additionally, positive emotion significantly influenced unplanned purchases. Meanwhile, store environments and sales promotions had no significant influence on unplanned purchases mediated by positive emotions.
\end{abstract}

Keywords: Unplanned Purchases, Store Environments, Sales Promotion, Positive Emotions.

\section{INTRODUCTION}

The development of the retail business in Indonesia is increasing from year to year. Based on data obtained from the Indonesian Retail Companies Association (Aprindo), Indonesia's retail business growth ranges from 10-15 percent per year. The Indonesian Retail Companies Association (Aprindo) revealed that in 2016, there was an increase in sales of around $10 \%$ in the national retail industry. The total value of retail sales in 2015 was 181 trillion, while in 2016, it reached 200 trillion. This increase occurred in line with the improvement in the Indonesian economy in 2016 [35].

One of the reasons for the increase in retail business sales is consumers' shift from traditional to modern markets [10]. Marketers need to attract consumers by offering an exciting store atmosphere, excellent service, and a wide variety of good choices [34]. The emergence of modern markets increases competition between traditional and contemporary offerings. The dimensions of market competition are product prices, product diversity, market location, and the store environment [10].

From the consumer side, consumers' inability to control themselves from the desire to buy a product can lead to purchases without planning. This phenomenon could happen due to many marketing stimuli around consumers. Consumers usually do not consider rationally and follow the company's impulse when making unplanned purchases [17]. Such a phenomenon, in turn, could affect the company's sales. Considering the effects of marketing stimuli and the store environment effect motivate the company to create exciting triggers and create a comfortable store environment to attract consumers to buy their product.

The store environment is a store condition designed and provided by the company by considering its target market to attract consumers' purchases [16]. The store environment is a physical and social character of the store environment, including physical objects (products and stores), store locations, and other people's social behavior. The goal of designing a store environment is influencing consumers to purchase a product. Besides providing an exciting store environment, sales promotion is another stimulus to attract consumers to buy its product. [4].

Sales promotion is a company's short-term incentives to encourage consumers' desire to buy a product. An exciting sales promotion will affect the consumer's mood to increase the consumer's probability of purchases. 
Sales promotion elements are frequency programs, coupons, product samples, and gifts. These sales promotion elements can impact a consumer's positive emotions [16].

According to [23], emotion is an effect of feelings and an essential factor in consumer purchasing decisions. There are two orthogonal dimensions of emotion, i.e., negative and positive emotions. Notably, positive emotions felt are the main determinants of consumer behavior. Moreover, positive emotions also essential factors of consumer purchasing decisions. Positive emotions will lead to more significant unplanned purchases [33]

Unplanned purchases are involuntary actions followed by a strong emotional response [28]. Unplanned purchases usually occur when a consumer encounters an attractive and comfortable store environment that provides various sales promotions that attract consumers to shop. Positive emotional feelings from consumers also greatly influence unplanned purchase behavior.

\section{LITERATURE REVIEW}

\section{Store Environment}

The store environment is a condition that has been planned by the company according to its target market so that it can attract consumers to make a purchase [16].

The store environment combines physical conditions such as architecture, layout, lighting arrangements, product display, color blending, air temperature, music, and an aroma, which will create an image in consumers' minds [8].

\section{Sales Promotion}

Promotions are sales plans that provide incentives to consumers to purchase specific products; by offering incentives to have the initial goal of attracting consumer interest [17]. Sales promotion is one of the promotional mixes. According to [16], sales promotion is a short-term incentive from companies to encourage consumers to buy a product.

Consumers see sales promotion as a social and physical aspect of the environment that can influence their affection and cognition responses [25]. The sales promotion elements include frequency programs, coupons, product samples, and prizes [16].

\section{Positive Emotions}

Emotion is an effect of feelings, which is an essential factor for consumers' purchasing decisions [23]. Emotions are relatively uncontrollable feelings that can strongly influence consumer behavior. There are two dimensions of emotions, i.e., positive and negative emotions [23].
In [1] model, three primary forms of emotion influence approach-avoidance behavior in a store environment. This response is known as the acronym PAD, namely: Pleasure, Arousal, and Dominance. The store atmosphere primarily involves affection in emotions that the customer may not be fully aware of while shopping [25].

\section{Unplanned Purchases}

An unplanned purchase is an act of buying that was not previously consciously recognized due to considerations or purchase intentions formed before entering a store. Unplanned purchase is an impulse with full force, persistence, and not being planned to buy something directly, without paying much attention to the consequences [28].

Consumers making unplanned purchases will tend not to consider the consequences. Consumers prefer to satisfy desires that appear suddenly without thinking about after-effects [14]

Unplanned purchases have factors that can cause this behavior, including the consumers' feelings and emotional state, the nature of unplanned purchases, normative evaluations of the speed of making unplanned purchases, self-identity, and demographics, such as age [14].

\section{The Effect of the Store Environment on Positive Emotions}

The store environment can pleasure consumers in shopping and add value from consumers to the products. This statement follows the theory expressed by [6] that the store environment involves affection in emotions when shopping in the store. Positive emotions are an effect of feelings in the way of excitement to shopping [23]. This opinion is also in line with [7], where the store environment is one of the essential factors that can cause positive emotions in consumers. Thus, the following hypothesis could be formulated:

H1: The store environment has a significant positive effect on positive emotions.

\section{The Effect of Sales Promotion on Positive Emotions}

Sales promotion is a form of direct persuasion using various measurable incentives to stimulate product purchases by promoting the reach and frequency of advertisements [2]. According to [23], positive emotion is an effect of feelings, which is an essential factor in consumer purchasing decisions. [31] argue that consumers may make unplanned purchases when they are interested, with attractive in-store items, advertisements, and promotions. This opinion is in line with the research results by [25] that advertising perceived by consumers is a social and physical aspect of the environment that can affect their affection and cognition responses. 
$\mathrm{H} 2$ : Sales promotion has a significant positive effect on positive emotions.

\section{The Effect of Store Environment on Unplanned Purchases}

According to [18], stores that can create a comfortable atmosphere will cause consumers to enjoy buying. The marketer needs to pay attention to the increased consumer's desire to shop. This research refers to the opinion of [22] that the existence of an attractive store environment can lead to a desire from within consumers to shop to increase the store's sales target indirectly. Designing a store environment involving four groups of activities: store planning, display of goods, store design, and visual communication. The company must display an attractive store environment so that unplanned purchases occur. Based on the previous discussion, the following hypothesis was proposed.

H3: The store environment has a significant positive effect on unplanned purchases.

\section{The Effect of Sales Promotion on Unplanned Purchases}

Sales promotions provided by the company aims to create consumer interest in the products offered. This statement corroborates the opinion of [26] that the delivery of a persuasive sales promotion, such as the process of listening, seeing, and the desire to use a product, will encourage purchase motives in consumers. In contrast, [19] proved that sales promotions did not significantly affect unplanned purchases. Besides, Sales promotions mostly carried out by companies are price discounts, shelf allocation, and a place to serve goods [1]. Hence, the following hypothesis could be formulated:

$\mathrm{H} 4$ : Sales promotion has a significant positive effect on unplanned purchases.

\section{The Effect of Positive Emotions on Unplanned Purchases}

[3] suggest that emotional states, such as pleasantunpleasant and passionate-not-passionate, affect consumer responses to the environment. This opinion is consistent with the research results from [23], which proved that consumers with positive emotions would make higher spontaneous purchases. According to [17], in making unplanned purchases, consumers usually do not think about the product's benefits to be selected and only follow the company's stimulus. It indicates that the higher the positive emotions, the higher the decision to make unplanned purchases. Therefore, the following hypothesis could be formulated:

H5: Positive emotions have a significant positive effect on unplanned purchases.

\section{The Effect of the Store Environment on Unplanned Purchases through Positive Emotions}

Positive emotions are an effect caused by feelings in the form of excitement to shopping [21]. It strengthens the opinion of [7] that the store environment is also one of the essential factors that generate consumer interest in doing business - purchases without prior planning. According to research conducted by [18], the store environment positively impacts unplanned purchases. Good store environment management will influence consumers' enjoyment of the store's to spend more time reviewing the store's products. It will result in unplanned purchases by consumers.

H6: The store environment has a significant positive effect on unplanned purchases through positive emotions.

\section{The Effect of Sales Promotion on Unplanned Purchases through Positive Emotions}

The sales promotion offered by the company aims to create consumer interest in products and services. This consumer interest can be in the form of positive emotions that arise to make a purchase. This theory agrees with [13] that unplanned purchases are consumer behavior in shopping where consumers do not have an initial plan to buy products. However, consumers make purchases influenced by the company's stimulus, namely in discounts, and consumers have a passionate mood for shopping. Then, the following hypothesis could be formulated:

H7: Sales promotion has a significant positive effect on unplanned purchases through positive emotions.

\section{RESEARCH MODEL}

This study examined the effect of the store environment and sales promotion on positive emotions and unplanned purchases. The logic of the phenomena was summarized in Figure 1.

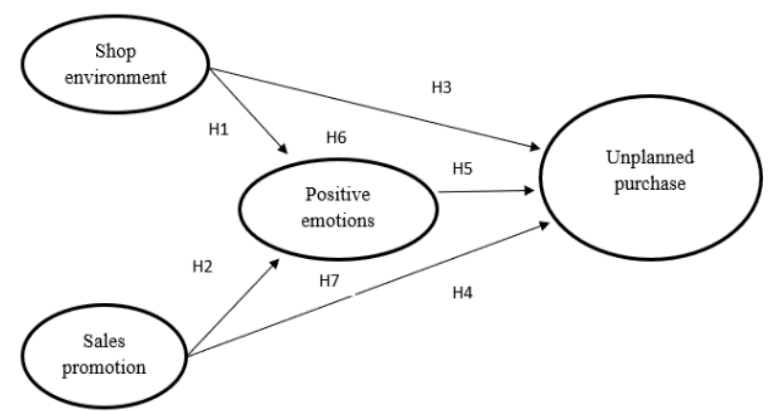

Figure. 1. Research Model 


\section{Population and Sample}

This study's population was people who lived in Yogyakarta. This study's respondents were Yogyakarta people who had made unplanned purchases at the hypermarket.

\section{Sampling Technique}

This study employed a non-probability sampling method using purposive sampling. The sample selection criteria in this study are as follows:

1. Respondents who were at least 17 years old

2. Respondents had performed unplanned purchases caused by sales promotions at least once in the last month at Hypermarket in Yogyakarta.

Referring to [11], the sample size in this study was 160. This research type utilized a causal survey. The instrument employed was a questionnaire. The questionnaires were distributed to the consumer of the global hypermarket in Yogyakarta Province of Indonesia.

Measurement of all variables in this study used a fivepoint Likert scale. The Likert scale tests how strong respondents agreed or disagreed on a 5-point scale [26]. This Likert scale can measure attitudes, opinions, and perceptions of a person or group about social events or symptoms.

\section{Data Collection Method}

The data collection is using an online survey. The instrument employed was a questionnaire. The questionnaire listed previously formulated statements and written statements that the respondent would answer, usually in a clearly defined alternative [26]. The area of questionnaires distribution is in a global hypermarket in the Yogyakarta area.

\section{Data Analysis}

The data analysis tool utilized was SEM (Structural Equation Modeling), operated through the IBM SPSS AMOS program.

\section{RESEARCH RESULTS}

\section{Validity and Reliability Test}

This study consisted of 20 statements representing each variable, with 159 respondents to test the instrument's quality in IBM SPSS AMOS. Table 1 showed the results of the validity and reliability test.
Table 1 Validity and Reliability Test Results

\begin{tabular}{|c|c|c|}
\hline Variable & $\begin{array}{l}\text { Factor } \\
\text { Loading }\end{array}$ & $\begin{array}{l}\text { Construct } \\
\text { Reliability }\end{array}$ \\
\hline \multirow{5}{*}{$\begin{array}{c}\text { Store } \\
\text { Environment }\end{array}$} & 0.793 & \multirow{5}{*}{0.872} \\
\hline & 0.801 & \\
\hline & 0.764 & \\
\hline & 0.680 & \\
\hline & 0.752 & \\
\hline \multirow{5}{*}{$\begin{array}{c}\text { Sales } \\
\text { promotion }\end{array}$} & 0.806 & \multirow{5}{*}{0.908} \\
\hline & 0820 & \\
\hline & 0833 & \\
\hline & 0841 & \\
\hline & 0.773 & \\
\hline \multirow{5}{*}{$\begin{array}{l}\text { Positive } \\
\text { Emotions }\end{array}$} & 0.778 & \multirow{5}{*}{0880} \\
\hline & 0.756 & \\
\hline & 0.737 & \\
\hline & 0.789 & \\
\hline & 0.795 & \\
\hline \multirow{5}{*}{$\begin{array}{l}\text { Unplanned } \\
\text { Purchases }\end{array}$} & 0828 & \multirow{5}{*}{0.899} \\
\hline & 0800 & \\
\hline & 0.822 & \\
\hline & 0.783 & \\
\hline & 0.768 & \\
\hline
\end{tabular}

Table 1 shows the results of testing validity and reliability. It showed that of the 20 questions tested, all of them were valid. These results were based on the criteria of loading factors $\geq 0.50$ [12]. The reliability testing showed that all of them were reliable of the four variables tested for reliability. It met the acceptable standard, namely, with the provisions of $\geq 0.70$ on the cut-off value of Contract Reliability (CR) to determine whether the data was reliable or not [12].

\section{Data analysis}

The data analysis technique used the modeling stage and structural equation analysis into seven steps, according to [12], as follows:

\section{Step 1: Theory-Based Model Development}

The first step in the SEM model is to develop a research model based on the concept of data analysis that has a justification. The relationship between variables and the model is a derivative of the theory. In general, this model consisted of two independent variables 
(exogenous): the store environment and sales promotion, one mediating variable: positive emotions, and one dependent variable (endogenous): unplanned purchases.

\section{Step 2: Constructing a Path Diagram}

The second step was to describe the research framework in a path diagram. Based on theory and previous studies, a path diagram could be made, as shown in Figure 2:

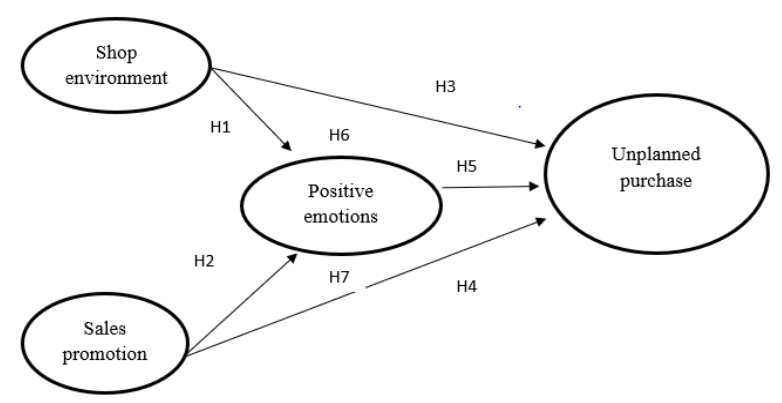

Figure. 2. Path Diagram

Figure 2 displays the research framework in a path diagram obtained based on theory and previous studies. This model included four variables that explained the causal effect between the store environment and sales promotion through positive emotions on unplanned purchases.

\section{Step 3: Converting the Path Diagram into a Structural Equation}

The third step was to convert the path diagram into equations, both structural equations and measurement model equations, as in Figure 3:

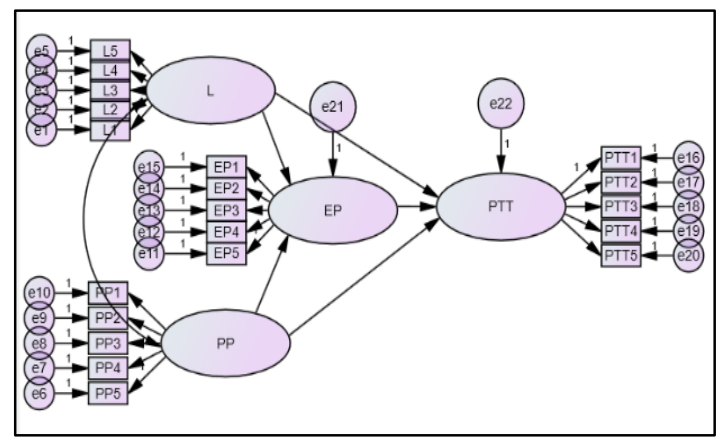

Figure. 3. AMOS Output Research Model

Figure 3 presents a path diagram converted into equations, structural equations, and measurement model equations using IBM SPSS AMOS. There were four variables: the store environment using five statement items, sales promotion with five statement items, positive emotions employing five statement items, and unplanned purchases with five statement items.
Step 4: Selecting Input Matrix Types and Estimates of the Proposed Model

a. Input matrix

Researchers entered the raw data input into AMOS, and then the program converted the data into covariance or correlation matrix data. The use of covariance matrix input was to test the theory. However, if the researchers only wanted to see the relationship pattern that did not require theoretical testing, then the correlation matrix input was quite acceptable for the research model. This study used a variant or covariance matrix input type.

b. Estimation of the proposed model

There are many types of structural equation modeling techniques, one of which is using the Maximum Likelihood Estimate (MLE). This study utilized the Maximum Likelihood Estimate (MLE). The model estimation used a minimum sample of 100-200 for good goodness-of-fit results [12]. Maximum Likelihood Estimate (ML) can be fulfilled with the following assumptions:

1. Large sample size

The number of respondents in this study was 159 , which referred to [12] theory. It argues that the number of representative samples is around 100-200. The sample size in this study has met the assumptions required in the SEM test.

2. Data normality test

The normality test was performed by looking at the $\mathrm{cr}$ (critical ratio) value for kurtosis (tapering) and skewness (slope) in the range of -2.58 to 2.58. If a cost of $\mathrm{cr}$ is higher than the critical value, the data distribution is not univariate familiar [12]. Testing data normality in this study can be seen in Table 2. For more details, see the attachment:

Table 2. Data Normality Test

\begin{tabular}{|l|l|l|l|l|l|l|}
\hline Variable & $\mathbf{m i n}$ & $\begin{array}{l}\text { Ma } \\
\mathbf{x}\end{array}$ & $\begin{array}{l}\text { Skewne } \\
\text { ss }\end{array}$ & cr & Kurtosis & cr \\
\hline PTT5 & $\begin{array}{l}2,00 \\
0\end{array}$ & $\begin{array}{l}5,00 \\
0\end{array}$ & -125 & -646 & -.429 & $-1,104$ \\
\hline PTT4 & $\begin{array}{l}2,00 \\
0\end{array}$ & $\begin{array}{l}5,00 \\
0\end{array}$ & -105 & -540 & -384 & -988 \\
\hline Variable & Min & $\begin{array}{l}\text { Ma } \\
\mathbf{x}\end{array}$ & $\begin{array}{l}\text { Skewne } \\
\text { ss }\end{array}$ & cr & Kurtosis & cr \\
\hline PTT3 & $\begin{array}{l}2,00 \\
0\end{array}$ & $\begin{array}{l}5,00 \\
0\end{array}$ & -209 & - & -.468 & $-1,205$ \\
& & & $\begin{array}{l}-1,07 \\
4\end{array}$ & & \\
\hline
\end{tabular}




\begin{tabular}{|c|c|c|c|c|c|c|}
\hline РTT2 & $\begin{array}{l}2,00 \\
0\end{array}$ & $\begin{array}{l}5,00 \\
0\end{array}$ & -200 & $\begin{array}{l}- \\
1,03 \\
0\end{array}$ & -500 & $-1,286$ \\
\hline PTT1 & $\begin{array}{l}2,00 \\
0\end{array}$ & & -.087 & -448 & -662 & $\begin{array}{r}- \\
1,705\end{array}$ \\
\hline $\begin{array}{l}\text { Multivari } \\
\text { ate }\end{array}$ & & & & & $\begin{array}{r}- \\
6,703\end{array}$ & $\begin{array}{r}- \\
1,425\end{array}$ \\
\hline
\end{tabular}

Table 2 shows the results of the normality test univariate. The majority were normally distributed because the critical ratio (cr) values for kurtosis (tapering) and skewness (slope) were in the -2.58 , referring to the 2.58 range. Therefore, the multivariate data have met the familiar assumptions because the value of 1,425 was in the range -2.58 to 2.58 .

3. Identification of outliers

The outlier is a condition in which data has unique characteristics and looks very different from other observations, and appears extreme. In multivariate analysis, the presence of outliers was tested by chi-square on the Mahala Nobis Distance Squared value at a significance level of $\mathrm{p}<0.001$, with the degree of freedom of several variables. It denoted the number of statement items. The distance was evaluated using X2 in degrees of freedom equal to the number of items for the measured variables used in the study. This research used 20 indicators. Results revealed that the outlier limit was 45,314. It signified that all data or cases whose values were higher than 45,314 represented a multivariate outlier state. Table 3 . showed the results of the outlier test.

Table 3. Outliers Normality Testing

\begin{tabular}{|c|c|c|c|}
\hline $\begin{array}{c}\text { Observation } \\
\text { number }\end{array}$ & $\begin{array}{c}\text { Mahala } \\
\text { Nobis d- } \\
\text { squared }\end{array}$ & p1 & p2 \\
\hline 94 & 41,045 & .004 & .443 \\
\hline 42 & 40,617 & .004 & .143 \\
\hline 93 & 37,367 & .011 & .237 \\
\hline 91 & 33,298 & .031 & .736 \\
\hline
\end{tabular}

Table 3 displays the outlier limit calculation. Results showed that there was no data greater than 45.314. Thus, it could be concluded that there were no outlier data in this study.

\section{Step 5: Assessing the Structural Model Identification}

The fifth step was to identify the model and look at the incredible identification results (meaningless) or not. If it is pointless, then the research model has identification problems. The identification problem is the proposed model's inability to produce a unique estimate.

Several ways to see whether there is an identification problem or not is to look at the estimation results. Requirements for SEM analysis is if the model identification results indicate an over-identified category [12]. The identification was based on the degrees of freedom of the model, as in Table 4 and Table 5:

Table 4. Computation of degrees of freedom (Default model)

\begin{tabular}{|c|c|}
\hline $\begin{array}{c}\text { Several distinct sample } \\
\text { moments: }\end{array}$ & 210 \\
\hline $\begin{array}{c}\text { Several different } \\
\text { parameters to be estimated: }\end{array}$ & 46 \\
\hline $\begin{array}{c}\text { Degrees of freedom (210 - } \\
46):\end{array}$ & 164 \\
\hline
\end{tabular}

Table 5. Result (Default Model)

\begin{tabular}{|l|l|}
\hline The minimum achieved & \\
\hline Chi-square & 341,295 \\
\hline Degrees of freedom & 164 \\
\hline Probability level & 0,000 \\
\hline
\end{tabular}

Table 4 and Table 5 exhibit that the degree of freedom value was 164 or positive. It means that the model was over-identified and feasible to proceed to the next step.

\section{Step 6: Assessing Goodness-of-Fit Criteria}

The sixth step was to assess the goodness-of-fit, aiming to determine how far the hypothesized model was fit or fitted the data sample [12]. Table 6 showed goodness-of-fit results

Table 6. Goodness-of-fit Index Test Results

\begin{tabular}{|l|l|l|l|}
\hline $\begin{array}{l}\text { The goodness of } \\
\text { fit index }\end{array}$ & $\begin{array}{l}\text { Cut-off } \\
\text { value }\end{array}$ & $\begin{array}{l}\text { Research } \\
\text { Model }\end{array}$ & Model \\
\hline $\begin{array}{l}\text { Significant } \\
\text { probability }\end{array}$ & $\geq 0.05$ & 0,000 & Less Fit \\
\hline Chi-Squares & 194,883 & 341,295 & Less Fit \\
\hline RMSEA & $\leq 0.08$ & 0.083 & Less Fit \\
\hline $\begin{array}{l}\text { The goodness of } \\
\text { fit index }\end{array}$ & $\begin{array}{l}\text { Cut-off } \\
\text { value }\end{array}$ & $\begin{array}{l}\text { Research } \\
\text { Model }\end{array}$ & Model \\
\hline GFI & $\geq 0.90$ & 0.833 & Less Fit \\
\hline
\end{tabular}




\begin{tabular}{|l|l|l|l|}
\hline AGFI & $\geq 0.80$ & 0.787 & Less Fit \\
\hline $\begin{array}{l}\text { The goodness of } \\
\text { fit index }\end{array}$ & $\begin{array}{l}\text { Cut-off } \\
\text { value }\end{array}$ & $\begin{array}{l}\text { Research } \\
\text { Model }\end{array}$ & Model \\
\hline CMIN / DF & $\leq 2.00$ & 2,081 & Less Fit \\
\hline TLI & $\geq 0.90$ & 0.917 & Good Fit \\
\hline CFI & $\geq 0.90$ & 0.929 & Good Fit \\
\hline
\end{tabular}

\begin{tabular}{|l|l|l|l|l|}
\hline & Estimate & se & cr & P \\
\hline $\begin{array}{l}\text { unplanned } \\
\text { purchases }\end{array}$ & & .499 & -912 & $\mathbf{. 3 6 2}$ \\
\hline $\begin{array}{l}\text { Positive } \\
\text { emotions } \\
\text { with } \\
\text { unplanned } \\
\text { purchases }\end{array}$ & -455 & & \\
\hline
\end{tabular}

Table 6 displays the goodness-of-fit test results. The model's overall results showed less fit, except for TLI of 0.917 and CFI of 0.929 , indicating a good fit. Thus, the goodness-of-fit test results on the standard model used in this study signified that the observed data were by the theory or model.

\section{Step 7: Interpreting the Hypothesis Estimates}

The seventh step was to interpret and estimate the model. Figure 4 showed the final model. While Table 7, Table 8, and Table 9 showed the statistical results.

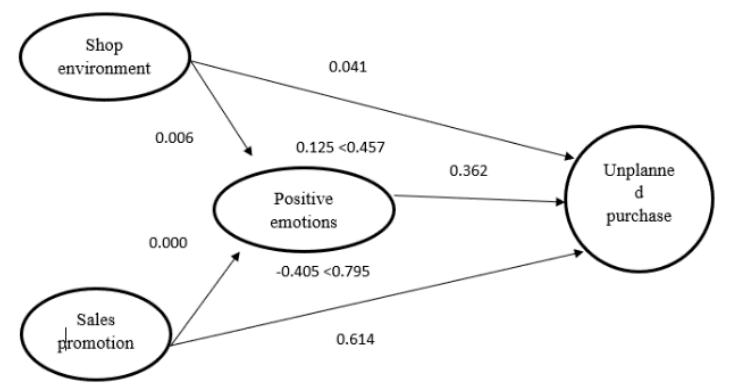

Figure. 4. Value of Direct Effect Between Variables

Figure 4 showed the final model estimate showing the results of the direct effect value between variables.

Table 7. Relationship Between Variables

\begin{tabular}{|l|l|l|l|l|}
\hline & Estimate & se & cr & P \\
\hline $\begin{array}{l}\text { The store } \\
\text { environment } \\
\text { with positive } \\
\text { emotions }\end{array}$ & .330 & .121 & 2,732 & $\mathbf{. 0 0 6}$ \\
\hline $\begin{array}{l}\text { Sales } \\
\text { promotion } \\
\text { with positive } \\
\text { emotions }\end{array}$ & .632 & .136 & 4,658 & $* * *$ \\
\hline $\begin{array}{l}\text { The store } \\
\text { environment } \\
\text { with } \\
\text { unplanned } \\
\text { purchases }\end{array}$ & 1,410 & .689 & 2,047 & $\mathbf{. 0 4 1}$ \\
\hline $\begin{array}{l}\text { Sales } \\
\text { promotion } \\
\text { with }\end{array}$ & .128 & .253 & .504 & $\mathbf{. 6 1 4}$ \\
\hline
\end{tabular}

The statistical test results in Table 7 illustrate the relationship between variables. The explanation for Table 7 is as follow:

a. The relationship of the store environment and positive emotions

Results showed that the cr value was 2.732. It indicated that the relationship between the store environment and positive emotions was positive, meaning that the higher the store environment's influence, the higher the positive feelings. The $\mathrm{p}$ value was $0.006<0.05$, which meant significant. Thus, (H1), assuming that the store environment has a significant positive effect on positive emotions, was accepted. It means that there was a direct influence between the store environment and positive emotions.

b. The relationship between sales promotion and positive emotions

The data processing results revealed that the $\mathrm{cr}$ value was 4.568. It denoted that the relationship between sales promotions and positive emotions was positive, indicating that the higher the sales promotion, the higher the positive emotions. The $\mathrm{p}$ value was $0.000<0.50$, meaning very significant. Therefore, (H2), stating that sales promotions significantly and positively affect positive emotions, was accepted. It means that there was a direct influence between sales promotions and positive emotions.

c. The relationship of the store environment and unplanned purchases

Based on the data processing results, it showed that the cr value was 2.047. It signified that the relationship between the store environment and unplanned purchases was positive, implying that the higher the store environment's influence, the higher the unplanned purchases. The p-value was 0.041 $<0.50$, meaning that it was significant. Hence, (H3), namely, the store environment has a significant positive effect on unplanned purchases, was accepted. It showed that there was a direct influence between the store environment and unplanned purchases. 
d. The relationship of sales promotions and unplanned purchases

The data processing results showed that the cr value was 0.504 . However, the p-value was $0.614>050$, indicating it was not significant. Thus, (H4), suspecting that sales promotions significantly and positively affect unplanned purchases, was rejected. Then, it means that there was no direct influence between sales promotions and unplanned purchases.

e. The relationship between positive emotions and unplanned purchases

Results showed that the cr value was 0.912 , and the $\mathrm{p}$-value was $0.362>0.50$, which means that it was not significant. Thus, (H5), which suspected that positive emotions have a significant positive effect on unplanned purchases, was rejected. Moreover, there was no direct relationship between positive emotions and unplanned purchases.

Table 8. Standardized Direct Effects

\begin{tabular}{|l|llll|}
\hline & PP & L & EP & PTT \\
\hline EP & .635 & .365 & .000 & .000 \\
PTT & $\mathbf{- . 4 0 5}$ & $\mathbf{. 1 2 5}$ & 1,252 & .000 \\
\hline
\end{tabular}

Table 9. Standardized Indirect Effects

\begin{tabular}{|l|llll|}
\hline & PP & L & EP & PTT \\
\hline EP & .000 & .000 & .000 & .000 \\
PTT &. $\mathbf{7 9 5}$ &. $\mathbf{4 5 7}$ & .000 & .000 \\
\hline
\end{tabular}

The statistical test results in Table 8 and Table 9 display the influence of the mediating variables. It could be concluded that:

a. Positive emotions' mediation between the store environment and unplanned purchases

Data processing results indicated that the value of standardized direct effects was 0.125 , and the standardized indirect effect value was 0.457 , then $0.125<0.457$. Thus, (H6) stated that the store environment significantly affects unplanned purchases through positive emotions and was rejected.

b. Positive emotions' mediation between sales promotions and unplanned purchases

Results showed that the value of standardized direct effects was -0.405 , and the standardized indirect effect value was 0.795 , then $-0.405<, 795$. Hence, $(\mathrm{H} 7)$, stating that sales promotions positively affect unplanned purchases through positive emotions, was rejected.

\section{RESULTS AND DISCUSSION}

Results stated that (H1), (H2), and (H3) were supported, however (H4), (H5), (H6), and (H7) were rejected. The discussion about the description per variable is as follows:

Hypothesis one (H1), assuming that the store environment has a significant positive effect on positive emotions, was accepted or supported. Hypothesis testing results showed $\mathrm{t}$ direct influence between the store environment and the positive emotion of consumers. These findings align with the previous research results by [7], who argue that the store environment is an essential factor that causes consumers' positive emotions. [6] also asserted that the store environment involves affection in the form of emotions when shopping in the store.

The results revealed that the higher the store environment's influence, the higher the positive emotions. An exciting store environment would arouse the comfort and pleasure feelings of consumers during shopping. These findings can give the hypermarket provider insight into developing a stimulating store environment to create positive consumer emotions.

Hypothesis two (H2), stating that sales promotions positively affect positive emotions, was supported. The hypothesis testing results concluded a direct influence between sales promotion and positive emotions of the consumers. These findings follow the previous research results by [15], which proved that sales promotions significantly affected positive emotions. Meanwhile, [25] state that consumers' promotion is a social and physical aspect of the environment that can affect consumer affection and cognition responses. [31] also affirm that consumers make unplanned purchases when goods or advertisements divert their attention.

The findings proved that the higher the effect of the sales promotion, the higher the positive emotions. An attractive sales promotion would create positive emotions in consumers when shopping. Thus, these results can give hypermarkets provider marketers insight into promotional activities by creating different innovations to generate positive emotions.

Hypothesis three (H3) stated that the store environment has a significant positive effect on unplanned purchases and was accepted or supported. Hypothesis testing results concluded a direct influence between the store environment and unplanned purchases on hypermarket consumers. These findings support [7] findings that the store environment is one of the essential factors that generate consumer interest in impulsive shopping. [18] Stores that can create a comfortable 
atmosphere will cause consumers to enjoy the buying process.

This study confirmed that the higher the store environment's influence, the higher the unplanned purchases. A good design of the store environment, such as design, color, and music, would attract consumers to shopping. These findings can give global hypermarkets providers and other marketers insight into developing store creativity to create impulsive purchases for consumers.

Hypothesis four (H4), suspecting that sales promotions significantly affect unplanned purchases, was rejected or unsupported. Hypothesis testing results showed no direct influence between sales promotions and unplanned purchases on Hypermarket consumers. These findings reinforce the research results from [21], which proved that sales promotions did not significantly affect unplanned purchases. However, these findings are not in line with the research results from [27], which found that the delivery of persuasive sales promotions, such as listening, seeing, and the desire to use a product, would encourage consumers' purchasing motives.

This study's results indicated that not all consumers were interested in sales promotions conducted by global hypermarket. Consumers consider the costs of the product since most respondents in this study were students. They had expenses for shopping only $\leq$ IDR $1,000,000$ per month. Therefore, this study's results can be insight for global hypermarket providers and other marketers to carry out promotional activities by creating different innovations every period to increase consumer desire to make purchases spontaneously.

Hypothesis five (H5), which predicts that positive emotions have a significant positive effect on unplanned purchases, was unsupported. There was no direct influence between positive emotions and unplanned purchases on consumers. This finding does not support the research results from [23], which proved that consumers who had positive emotions would spontaneously make higher purchases.

Results denoted that consumers considered several factors, such as purchase priorities, goods needed, price, and product benefits, before deciding to make a purchase. However, this study's findings give insight into global hypermarkets and other marketers to increase in-store stimuli that can lead to unplanned purchases.

Hypothesis six (H6) states that the store environment has a significant positive effect on unplanned purchases mediated by positive emotions and does not have any support. Hypothesis testing concluded that positive emotions influence positive emotions between the store environment and unplanned purchases in global hypermarket consumers. In agreement with the findings of [17], the store environment's influence positively impacted unplanned purchases. A good store environment design could influence consumer behavior to enjoy the store's atmosphere more to spend a longer time. They will browse the products offered, which results in unplanned purchases by consumers. Although the store environment can influence positive emotions, positive emotions do not necessarily influence unplanned purchases. Consumers may feel that during their shopping activities, they cannot enjoy the retail atmosphere. In return, this situation will not affect purchases so that consumers do not make purchases out of necessity.

Hypothesis seven (H7), which assumes that sales promotions significantly and positively affect unplanned purchases mediated by positive emotions, was unsupported. Hypothesis testing concluded that positive emotions influence positive emotions between sales promotions and unplanned purchases. This finding confirms research results from [13], which affirms that unplanned purchases are consumer behavior in shopping, where they have no prior planning to buy products. Consumers will also make purchases influenced by the company's stimuli, namely in discounts, or consumers have a passionate mood for shopping. Consumers tend to consider several factors before deciding to purchase, such as purchase priorities, goods needed, price, and benefits. The results indicated that consumers were not interested in sales promotions conducted by Global hypermarkets to not make purchases outside of their needs.

\section{CONCLUSION}

The research results and discussion described in the previous section showed that the store environment and sales promotion positively and significantly affected positive emotion. The store environment had a significant positive effect on unplanned purchases. However, sales promotion had no significant impact on unplanned purchases. Additionally, positive emotion significantly influenced unplanned purchases. Meanwhile, store environments and sales promotions had no significant influence on unplanned purchases mediated by positive emotions.

\section{Research Limitation}

1. The criteria for selecting samples that required respondents to make purchases without planning due to sales promotions at least once in the last three months were challenging to find because most respondents did not remember whether they shopped with planning or without planning.

2. There might be some habits of information provided by respondents through questionnaires. It did not indicate actual conditions because most respondents were in a hurry when filling out the questionnaire. They could not remember well the environment, 
promotions, or feelings when they were shopping.

\section{Suggestion}

1. Researchers who wish to re-examine this research suggested replacing the sales promotion variable with other variables related to factors that can influence unplanned purchases.

2. Researchers who want to investigate this topic are advised to add or replace sample selection techniques by direct interviews with consumers to minimize habits and show the actual conditions

\section{REFERENCES}

[1] Abratt, Russell; Goodey, Stephen Donald. 1990. Unplanned Buying and In-store Stimuli in Supermarkets. Managerial and Decision Economics, Vol. 11,111-121.

[2] Adelaar, Thomas; Susan Chang; Karen M Lancendorfer; Byoungkwan Lee; dan Mariko Morimoto. 2003. "Effects of media formats on emotions and impulse buying intent." Journal of Information Technology.

[3] Babin, BJ, \& Attaway, JS (2000). Atmospheric Affect as A Tool for Creating Value and Gaining Share of Customer. Journal of Business Research, 49 (2), 9199.

[4] Baker Julie, A. Parasuraman, Dhruv Grewal, Glenn B. Voss. 2002. The Influence of Multiple Store Environment Cues on Perceived Merchandise Value and Patronage Intentions. Journal of Marketing: April 2002, Vol. 66, No. 2, pp. 120-141.

[5] Berman, Barry, and Joel R, Evans. 2007. Retail Management. New Jersey: Prentice-Hall.

[6] Donovan, RJ, and Rossiter, JR, 1982, Store Atmosphere: An Environment Psychology Approach. Journal of Retailing, 58 (Spring): 34-57.

[7] Dunne, P, and Lusch, R., 2008. Retailing Edition. Mason: Thomson Higher Education.

[8] Engel, James et al., 2006. Consumer Behavior. Mason: Permissions Department, Thomson Business and Economics.

[9] Fauziyah, A. Febrina. 2017. The Influence of Store Environment Factors on Impulsive Purchasing Behavior with Emotional Conditions as an Intervening Variable: A Test of the Mehrabian and Russell Models. Thesis at the Muhammadiyah University of Yogyakarta.
[10] Fox, Edward, J, and Raj, Sethuraman. 2006. Retail Competition, in Retailing in the 21st Century: Current and Emerging Trends, Kraft Manfred and Mantrala.

[11] Gray, Amel, Dani-Elkebir, Maachou, Bensaid, Mohamed. 2014. The Impact of Environmental Factors on Impulse Buying Behavior Using the Mehrabian and Rusell's Framework. Leonardo Journal of Science. Pp: 101-114.

[12] Hair J et al., 2010. Multivariate Data Analysis. Issue 7. New Jersey: Prentice-Hall.

[13] Hawkins, I. Del, Mothersbaugh, I., David, and Best, JR (ND). Consumer Behavior: Building Marketing Strategy, 10 / E. The Mc. Graw Hill Companies. Inc, New York. The United States of America.

[14] Kacen, JJ, \& Lee, JA, 2002. The Influence of Culture on Consumer Impulsive Buying Behavior. Journal of Consumer Psychology.

[15] Karbasivar, A., and Yarahmadi, H. 2011. Evaluating Effective Factors on Consumer Impulse Buying Behavior. Asian Journal of Business Management Studies, 2 (4), 174-181.

[16] Kotler and Keller. 2016. Marketing Management, England: Pearson.

[17] Lawson, R., \& Todd, S. (2002). Consumer Lifestyles: A Social Stratification Perspective. Marketing Theory, 2 (3), 295-307.

[18] Lin, Long-Yi; Lu, Ching-Yuh, 2010. "The Influence of Corporate Image, Relationship Marketing, and Trust on Purchase Intention: The Moderating Effect of Word of Mouth." Tourism Review, Vol.65 No. 3, 2010. pp. 16-34.

[19] Mattila, Anna S, Dan Wirtz, J. 2008. The Role of Store Environment Stimulation and Social Factors on Impulse Purchasing. Journal of Services Marketing, 22 (7), 562-567.

[20] Mehrabian A. and Russell, JA, 1974, an Approach to Environmental Psychology. in Fisher, Feffrey D., Paul A. Bell, and Andrew Baum (1984). Environmental Psychologist. 2nd ed. New York: Holt, Rinehart, and Winston.

[21] Nagadeepa. C, J. Tamil Selvi, PA (2015). Impact of Sale Promotion Techniques on Consumers' Impulse Buyıng Behaviour towards Apparels at Bangalore. Asian Journal of Management Sciences \& Education, 4 (1), Annamalai University, India.

[22] Nistorescu, T \& Barbu, CM (2008). Retail Store Design and Environment as Branding Support in the Services Marketing. Management \& Marketing Craiova, 1 (08). 
[23] Park, Eun Joo, Kim, Eun Young, Forney, Judith Cardona. 2006. A Structural Model of FashionOriented Impulse Buying Behavior. Journal of Fashion Marketing and Management, 433-446.

[24] Park, Eun Joo \& Kim, Eun Young. 2008. Effect of Consumer Tendencies and Positive Emotion on Impulse Buying Behavior for Apparel. Journal of Korean Society, 980-990.

[25] Peter, JP, and JC Olson. 2014. Consumer Behavior and Marketing Strategy (7th Ed.). London: Mc. Graw-Hill.

[26] PT Matahari Putra Prima Tbk. (2016). Laporan Tahunan PT Matahari Putra Prima Tbk "Transitioned for Sustainable Growt". Diambil kembali dari PT Matahari Putra Prima Tbk. website: www.mppa.co.id

[27] Rajagopal. 2010. Consumer Culture and Purchase Intentions for Fashion Apparel. Egade Business School, (March): 1-12.

[28] Rook, DW, 2009. The Buying Impulse. The Journal of Consumer Research. 14 (2): 189-199.

[29] Sekaran, U. 2014. Research Methods for Business. Jakarta: Four Salemba.

[30] Stern, H., 1962, A the Significance of Impulse Buying Today, Journal of Marketing, Vol. 26 April, pp. 59-63.

[31] Tendai, M, and C. Crispen. 2009. In-Store Shopping Environment and Impulse Buying. South Africa: African Journal of Marketing Management.

[32] Thompson, JA, Strickland, AJ, and Gamble, EJ 2010. Crafting and Executing Strategy, Seventeenth Edition, Mc Graw- Hill / Irwin, Inc., New.

[33] Tirmizi, MA, 2009. An Empirical Study of Consumer Impulse Buying Behavior in Local Markets. Journal of Scientific Research. 28 (4): 2522-532.

[34] Weitz, Barton, and Mary, Brett, With field. 2006. Trends in US Retailing. Retailing in the $21 \mathrm{st}$ Century. Pp: 59-75.

[35] www.aprindo.org 